Robin L. Henrikson (USA)

\title{
Building Purposeful Superintendent and School Board Relationships Through Examining the His- torical Narrative of Evolving Roles
}

\begin{abstract}
The author presents a summary of the changing role of the traditional superintendent within the United States through the lens of how this work can be challenged or encouraged by the relationship with her or his respective board. The author emphasizes how the evolving roles of both the superintendent and school board member have contributed to the lack of clarity around their respective responsibilities that has influenced relational factors between these two groups. The importance of building, nurturing and sustaining relationships between the superintendent and school board in order to be proactive and prepared to encounter the many issues that school districts face daily is integral to this conversation. School boards and superintendents must understand how to collaborate beyond simply abiding by their delegated role at the time to flourish and support a successful school district.
\end{abstract}

Key Words: superintendent, school board, evaluation, district leadership, communication

$* * *$

摘要 (Robin L. Henrikson: 通过对角色变换的历史性叙事的研究, 来建立管理者与学校理事会之间的有目的 的矢系。作者通过这样一个问题总结了美国传统管理者的角色变换, 即这项工作是如何通过与现任理事 会的矢系被挑战或被鼓励的。作者强调了管理者和校理事会成员角色的不断演变是如何导致各自职责的 不明确性，这样的矢系因素使得这两个群体之间均受到影响。建立，维护和维持校长与学校当局之间矢 系的积极性与主动性, 并准备应对学区每天要面临的诸多问题与挑战, 这一点的重要性是此一次对话不可 或缺的组成部分。校领导与管理者需要学会看到并懂得他们是如何能够通过纯粹地扮演好自己被授权的 角色而彼此进行合作，进而发展和支持一个成功的校区。

关键词：管理者，校务委员会，评估，区领导

摘要(Robin L. Henrikson: 通過對角色變換的歷史性敘事的研究, 來建立管理者與學校理事會之間的有目的 的關係。作者通過這樣一個問題總結了美國傳統管理者的角色變換，即這項工作是如何通過與現任理事 會的關係被挑戰或被鼓勵的。作者強調了管理者和校理事會成員角色的不斷演變是如何導致各自職責的 不明確性，這樣的關係因素使得這兩個群體之閒均受到影響。建立，維護和維持校長與學校當局之間關 倸的積極性與主動性，並蕉備應對學區每天要面臨的諸多問題與挑戰，這一點的重要性是此次對話不可 或缺的組成部分。校領導與管理者需要學會看到並喠得他們是如何能夠通過純粹地扮演好自己被授權的 角色而彼此進行合作，進而發展和支持一個成功的校區。

關鍵詞：管理者，校務委員會，評估，區領導

Zusammenfassung (Robin L. Henrikson: Aufbau zielgerichteter Beziehungen zwischen Superintendent und Schulrat durch Untersuchung der historischen Narrative von sich entwickelnden Rollen): Der Autor gibt eine Zusammenfassung der sich ändernden Rolle des traditionellen Superintendenten in den Vereinigten Staaten durch die Frage, wie diese Arbeit durch die Beziehung zum jeweiligen Vorstand herausgefordert oder gefördert werden kann. Der Autor betont, wie die sich entwickelnden Rollen sowohl des Superintendenten als auch des Schulvorstandsmitglieds zu der Unklarheit über ihre jeweiligen Verantwortlichkeiten beigetragen haben, 
die die Beziehungsfaktoren zwischen diesen beiden Gruppen beeinflusst haben. Die Bedeutung des Aufbaus, der Pflege und der Aufrechterhaltung der Beziehungen zwischen dem Schulleiter und den Schulbehörden, um proaktiv und bereit zu sein, sich den vielen Problemen zu stellen, mit denen die Schulbezirke täglich konfrontiert sind, ist integraler Bestandteil dieser Konversation. Schulleitungen und Superintendenten müssen lernen, zu sehen und zu verstehen, wie sie über die reine Einhaltung ihrer damaligen delegierten Rolle hinaus zusammenarbeiten können, um einen erfolgreichen Schulbezirk zu entwickeln und zu unterstützen.

Schlüsselwörter: Superintendent, Schulausschuss, Evaluation, Distriktleitung

\begin{abstract}
Аннотация (Робин Л. Хенриксон: Выстраивание целенаправленных отношений между суперинтендантом и советом школы на основе изучения исторических нарративов о меняющихся социальных ролях): автор представляет обзор дискурса о трансформирующейся роли супринтенданта в США, рассматривая вопрос, как этот вид деятельности, завязанный на контактах с администрацией школы, должен отвечать на вызовы времени и находить соответствующую поддержку. Автор акцентирует внимание на том, как трансформация ролей, наблюдаемая с обеих сторон (суперинтендант - администрации школы), спровоцировала ситуацию, когда представления о компетентностных полномочиях участников дискурса размыты, и как это повлияло на характер взаимоотношений между данными группами. Значение выстраивания отношений между руководством школы и руководителями системы школьного образования, необходимость налаживания данного контакта, его поддержания и сохранения на стабильной основе является интегративной составляющей данного дискурса. Это необходимо для того, чтобы обладать необходимой инициативой и быть готовым к решению тех проблем, с которыми ежедневно приходится сталкиваться органам системы школьного образования. И администрация школ, и суперинтенданты должны научиться видеть и понимать, как выстраивать совместную работу не только в рамках определенных ранее компетенций, но и в свете происходящих трансформационных процессов - на благо успешного развития школьных округов.
\end{abstract}

Ключевые слова: суперинтендант, комитет по школьному образованию, администрация округа

He (the superintendent) is hired and can be fired by the board so he always has to be circumspect in his behavior toward them. He is also extremely vulnerable to the press and to pressure groups in the community. Finally, he can be and usually is severely limited because of our inadequate financial arrangements for supporting our schools. So, his condition is one of power as regards the teachers and one of weakness so far as the school board and the community are concerned. Nevertheless, despite the weakness of some aspects of his position, he is still the most important person in any school system in terms of potential for influencing the quality of work that goes on in the schools. (Callahan, 1966)

\title{
Introduction
}

With a recognition that school boards do in fact have an impact on student learning (Alsbury, 2015) it is essential to better understand not only how they operate effectively as one voice, but also how they support the leader of the school district: the superintendent. There are many opportunities for school boards and superintendents to better learn their respective roles and responsibilities within a school district. It is also imperative for these individuals to adopt strategies for establishing a foundation for a strong working relationship to navigate what is becoming a more political and divisive educational landscape. There is startling little research on the relationships between school board and superintendents (Shelton, 2015). Communication, collaboration and ongoing relationship-building are key skills 
that without, often leave the superintendent and school boards at odds with one another (Mountford, 2008).

\section{Evolving Roles of the Superintendent and School Board}

Role of Superintendent Over the Past Two Centuries. Superintendents were once hired as state representatives until the common school model became more pronounced, recognizing the local characteristics, needs and demographics of individual districts that needed representations. Over the past 200 years, the role of the superintendent has evolved from a managerial position, to one of an instructional and political leader within a community (Kowalski \& Brunner, 2011). Interestingly, education was not one of the responsibilities of the federal government by the architects of the Constitution, but allocated to states to control (Bogotch, 2004). In the early 1800's, states recognized their responsibility for education and leadership in schools (Newsom, 1932; Stufflebeam, 1994). The first superintendents were representatives for schools within an entire state, whose primary goals were to plan common school systems, report on management of public funds, and provide information to the state regarding schoolrelated issues. With emerging recognition of the unique context and needs between rural regions and urban areas, including handling issues of inequity, there was a push to advocate for the common school model. Thus, local control was given to districts and/or schools to hire superintendents to become their representative (Kowalski, \& Brunner, 2011).

This attention towards local control was partially the result of a general dissatisfaction with the school system at the time by the Commissioner of Education, Horace Mann in 1837. He analyzed many school systems across the world and with the help of a committee, made efforts to reform the education system through the recharacterizing of both the school board and superintendent (Ellis, Golz, \& Mayrhofer, 2014). Politics within cities grew and the rise of special interests amongst school board members became increasingly present. Therefore, it was decided that less power ought to be given to fewer school board members to represent the interests of the community and provided the superintendent the authority to run the district's operations. This sole individual was held accountable for the management by the board and community (Callahan, 1966). Thus, in 1837, the first superintendent, Oliver Steele, was appointed in Buffalo, NY and two years later Nathan Bishop was appointed in Providence, RI (Mowry, 1894). Ironically, as Stephens (2007) noted, the board of directors still maintained authority over various departments and programs within the schools whereas the superintendent, while still accountable, had very little actual authority over the decisions made. Mowry (1894) explained that the superintendent would only be called upon to perform certain duties under the direction of a school board member who provided oversight via a school committee, rendering the superintendent virtually powerless. Struggling with power and authority between these two roles was an embedded and perhaps unintended tension from the very origins of these roles (Nir \& Eyal, 2003). This tenuous relationship and role distinction between school board members and the superintendent and are still apparent today.

The evolving role of the superintendent from the early 1900's to present was conceptualized through four roles: a) teacher-scholar, b) organizational manager, c) statesman, or democratic leader, and d) applied social scientist. (Callahan,1966). Kowalski (2005) added a fifth role that carries into our present day: superintendent as communicator. The first role that characterized the superintendent position was that of a "teacher of teachers," or as Callahan (1966, p. 187) wrote, "scholarly educational leaders." This role characterization spanned from about 1865 to 1910. The purpose of the superintendent during this time was to be an instructional leader who supervised classroom instruction and curriculum. This in 
turn allowed school board members to focus on legislative functions and managing and overseeing district operations (Glass, Bjork, \& Brunner, 2000; Kowalski, 1999; 2005). These superintendents were teachers of teachers, known scholars, and experts in pedagogical matters. Superintendents saw themselves as educational leaders of their communities, both within the schools and amongst the community, while the most astute superintendents also being attentive to financial and public relations-related issues (Bogotch, 2004; Callahan, 1966).

The second role of superintendent, spanning about thirty years, was that of an "organizational manager" (Kowalski, 2005; Bjork, 2008). During this era, millions of immigrant families entered the United States, the majority of whom remained in eastern cities. While most school districts were in rural areas, most school children began to attend urban school districts. This in turn created a rapid increase of school-age children enrolling in urban public schools (Callahan, 1966). This left educators grossly unprepared and underfunded in their ability to provide quality educational programs. Perspectives on increasing the efficiency of education took hold as large city school districts grew in student numbers and school districts were forced to tax citizens in order to deal with the financial hardships that had been growing. At this same time, an ideology of the "prestige of the businessman" profile was on the rise (Bogotch, 2004; Kowalski \& Keedy, 2005). This resulted in shifts toward a more corporate, taskoriented model of school board and superintendent governance (Glass, et al., 2000; Kowalski, 2005). Growing skepticism and dissatisfaction with the traditional model of education grew to more of a business model of education with pressure for reformation from special interest groups (Bogotch, 2004; Callahan, 1966; Glass, et al., 2000). During this shift, control of more decision-making was granted to the superintendent as the need for superintendents to understand both organizational efficiency and be equipped with financial acumen increased (Callahan, 1966; Glass, et al., 2000). The impacts of this era are still apparent today through the ways in which courses are designed as individual entities with educators and, especially in higher grade levels, experts of specific topics.

After the Great Depression and through the second World War, a shift towards more of democratic, community-minded education spawned the next role of the superintendent- that of an "educational statesman" or in other words, "democratic leader" (Bjork, 2008; Kowalski, 2005). This was the result of an often outright rejection of the business model within the educational setting. This shift towards a community-centered, political and democratic leader shaped the superintendent role during this time (Stephen, 2007). Kowalski (1991) wrote,

Specific obligations include (1) building a symbiotic relationship between the school district and the community, (2) informing the public of educational needs, (3) bringing people together to create visions and goals, (4) interpreting educational goals to the public, and (5) building support for school initiatives. As policy making shifts toward the local level because of deregulation and decentralization, these responsibilities become increasingly important (p. 314).

However, general discontent emerged regarding the lack of accountability and recognition of the complexity of this position. The "educational statesman" nomenclature also did not acknowledge the need to be astute to the increasing level of special interest groups involved in public education (Bjork, 2008).

The fourth role of the superintendent became the "applied social scientist" that spanned mid-1950's to the mid 1970's (Callahan, 1966; Bjork, 2008). This role emerged to be more attentive to the political tensions and issues that influenced the superintendent's decisions as well as the governance of the school district. Superintendent preparation programs increasingly focused on understanding the community, social and political issues that would impact a district and hence, the success of a superintendent. Thus, the increasingly complex role of the superintendent emphasized and sought to analyze edu- 
cational leadership practices that which characterizes an effective leader. This included a greater understanding of organizational theories both within the educational setting as well as within the community (Fusarelli and Fusarelli, 2005). While the role of the superintendent is ever evolving, the effort to study politics within the educational system was reinvigorated during the early 1970's and continues today (Bjork, 2008; Fusarelli \& Fusarelli, 2005).

This final shift to superintendent as "communicator" (mid-1970's) is still prevalent in today's era of education reform (Bjork, Kowalski, \& Browne-Ferrigno, 2014). This shift came about due to an increased importance on high stakes accountability, No Child Left Behind and Race to the Top initiatives that have charted the landscape of public education over the past thirty years. The superintendent is required to understand how micropolitics shape both the organizational setting, allocation of resources and community relations (Bjork, 2008). With this is the paradigm shift from working in isolation to collaborating and distributing leadership amongst an organization (Bjork et al., 2014). Emphasis on testing, results-oriented programs and improved teacher evaluation systems, coupled with the lack of funding for education, created an even more complex set of responsibilities for the superintendent. With this increasing level of accountability, superintendents needed to become expert communicators to the educators within their district, their community and serve as the primary source of information to their boards (Bjork et al., 2014). In fact, many states and certification standards for superintendents include effective communication as a competency (Kowalski, 2005). However, therein lies the issue with conceiving the superintendent as the communicator; it is difficult to measure or qualify what effective communication is given the various audiences and purposes of this role (Kowalski \& Keedy, 2005). As such, various tensions arise amongst groups who work with the superintendent, with perhaps the highest stake relationship: the school board.

History and Role of the School District Board of Directors. Such as in the case of the evolving role of the superintendent, the school board director role has changed over time. However, two guiding principles have remained consistent throughout history. School board members have always felt pressure to listen and advocate on behalf of their constituents and be expert decision-makers for running an efficient school system (Merz, 1984). One can trace the history of the superintendent role to see how the balance between this position and the school board has shifted over time and in relation to one another.

Perhaps the earliest recorded history of the school board was in 1645. The town of Dorchester, New England ordered that,

three able and sufficient men of the plantation be chosen to be wardens or overseers of the school, who shall have the charge, oversight, and ordering thereof and of all things concerning the same in such manner as is hereafter expressed and shall continue in their office... (Mowry, 1894, p. 39).

Mowry (1894) made the case that during this time, representatives were often educated, clergy members, physicians or members of the legal profession. Serving on this committee was not perceived as a political stepping stone nor did it have any perceived underlying special interest intentions. However, as populations grew into cities, in 1895 Mowry advocated for a school superintendent appointment who better understood the study of education (Mowry, 1894; Callahan, 1966). In part of his proclamation, one of the founders of the American school system Horace Mann, included the need for school districts to be controlled by lay boards of education in order to provide heterogenous representatives 
including non-partisan and non-sectarian (Kirst, 2008). Thus, in 1837 the first superintendent was appointed in Buffalo, NY (Mowry, 1894) as described in the previous section.

Modeled after the New England method of controlling schools through town meetings, school boards were first established in Massachusetts in 1826. The principle of maintaining local control over education created significant growth in school board governance in the 1800's (Kirst, 2008). Joseph Rice, an early advocate of progressive education, believed there were four basic factors influencing the quality of schools; school boards being one of these. However, typically during this time school board members were selected according to special interests, politics and perceived power (Callahan, 1966). School boards in rural communities continued to grow but in urban areas, due to perceived partisan politics and corruption within the education system, reform aided in actually centralizing operations, expertise and efficiency through non-political control at the district level (Kirst, 2008). At this time, New York City had 21 members at the time and appointed by the mayor. Some of the reforms included reducing the number of school board members, elected at large, and void of political connections (Callahan, 1966; Gersman, 1970; Kirst, 2008).

Perhaps it was the seminal work of Draper, Powell and Poland called "The Committee of Fifteen," commonly referred to as "The Draper Report" (Callahan, 1966; Merz, 1984) that attempted to clearly define the work of the school board and recognized the issues inherent to this position. The authors of this report advocated for complete removal of politics within the school board position and to reduce the number of board members to no more than 5-7 depending on the size of the district. The authors believed that the mayor should appoint the superintendent as well as the school board. Their argument was that the mayor is looking out for the best interests of the community as a whole and the persons leading the schools should promote citizenry and the best interest of the community as a whole. The authors of the Draper Report also advocated for the school board to not be able to benefit personally from their work in order to ensure the best individuals for this work and to eliminate partisanship. This appeal sparked so much debate that school boards were nearly dismantled during this time (Draper, Powell \& Poland, 1895; Merz, 1984). A couple of other interesting things to note about this report is their advocacy of two branches of governance. One branch called the "School Director" who oversaw the executive, business side of the administration as well as veto power and the other branch called the "School Council." This branch would be the carrying out of duties of the school operations, i.e. the superintendent (Draper et al., 1895). However, they also advocated for the school board director to "give his entire time to the duties of his position" (p. 121). While the Draper Report advocated for these two positions to be equal, the veto power of the "School Director" branch intentionally cast this position more powerful than the other. While obviously not all of these recommendations were implemented, the Draper Report launched years of debate over the role and purpose of the school board which attempted to more clearly define roles between these two groups well into the $20^{\text {th }}$ century (Merz, 1984). With the seemingly unclear and often times interchangeable roles of both the school board and the superintendent, it rose to the highest level of conflict in 1895, influenced by Draper, Rice (an educational leader) and other prominent educators at the time (Draper et al., 1895; Callahan, 1966). As Callahan (1966) summarizes, the basic issue put forth by Rice was simply: who would run the schools?

This debate spanned years. After much debate the general consensus was that the board is in charge of hiring the superintendent who would be in charge of four major areas: the control of the course of study, the selection of textbooks, selection of teachers and supervision (Callahan, 1966). However, no matter how much independence the superintendent had, the school board still had the authority to hire, retain or dismiss the superintendent which maintained that power hierarchy between the school board and superintendent. This continued to create difficulties with the school board overstepping 
their duties and interfering with the responsibilities of the superintendent (Bjork, Glass, \& Brunner, 2005).

The expectations of the school board in the early part of the $20^{\text {th }}$ century emphasized board members be experts in educational issues and less on the politics within the community (Merz, 1984). Those running for the position in an election weren't required to have any specific mandate or platform from which they would be knowledgeable about. Moreover, they lacked opportunities and knowledge of the daily operations of the district which prohibited their ability to question decisions made by the superintendent. (Merz, 1984; Kirst, 2008). In the 1920's board members often held professional roles and/or were businessmen within their communities and typically could only afford one to two times per month to meet. In fact, Cubberly, dean of the Stanford School of Education advocated for school board members to be professional businessmen and bankers since they would be efficient and not meddle in the affairs of the district operations (Mountford, 2008). It was at this time that Cubberly also advocated for the need to clearly delineate the work of the board and the superintendent. He wrote that the responsibility of the superintendent was to operate the schools while the board was to decide policy (Mountford, 2008). While the roles were now clearly defined, challenges continued with the implementation of this practice.

The latter half of the $20^{\text {th }}$ century led to various role changes by the board, led mostly by the given period's political and social pressures (Merz, 1984; Cistone, 2008; Kirst, 2008). By the 1960's their primary responsibility was to mediate policy conflicts and was often little more than a rubber stamp of approval (Kirst, 2008). The onset of the 1980's led to a huge inception of initiatives and programs as well as special interest groups being introduced into educational policy. Programs then required in public education included special education, bilingual education, and health services to name just a few (Kirst, 2008). These policies reduced the local power of the board in some ways due to the requirements from the government to implement these programs rather than leaving the power to the board to make these decisions. With the onset of the $21^{\text {st }}$ century, the National School Board Association proclaimed that the two primary purposes of the school board were to ensure student achievement and engagement with the community (Gemberling, Smith, \& Villani, 2000). Alsbury (2015) wrote that school boards across the United States varied widely, but typically take one of two extremes. The first being a political entity solely obligated to be a communication conduit between the schools and public. The other extreme is the call for board members to participate in every facet of the school. As Albury (2015) also noted, this is reflective of the origin of school board members. With more accountability for implementation of academic and other student programs, more emphasis was on school boards to ensure student learning was prioritized (Hess \& Meeks, 2010). Perhaps because of this pressure, there has been an emphasis on more of a distributed leadership model of governance that emphasizes leadership rather than simply oversight, not only with the superintendent, but school leaders and community (Hess \& Meeks, 2010). Given the details of this report, the evolving role of the school board is ongoing.

\section{Demographics of Superintendents and School Board Directors}

One of the main sources of conflict, according to Mountford (2008) is equality of representation. Therefore, it was important to include a section in this article on the demographics of individuals holding these two roles. The review of research on the roles and responsibilities of both superintendents and school board directors shows that up until the mid 1900's, they were encouraged to be businessmen and men of good standing within the community (Callahan, 1966; Draper, et. al, 1895; Mountford, 
2008). However, research suggests that role identity of school board members shape the ways in which they make decisions (Bartanen, Grissom, Joshi \& Meredith, 2018).

The seminal study conducted in 2000 by Glass, Bjork and Brunner provide a comprehensive overview of the superintendency, both in personal characteristics and in relation to their work. They found that almost $95 \%$ were white, and $86.6 \%$ were male. In a 2007 study by Glass \& Franceschini in partnership with the American Association of School Administrators (AASA), women are comprised of $22 \%$ of the superintendents across the United States and only 6\% are non-white. A follow-up report was published nearly a decade later which shows that females make up $27 \%$ of the superintendent population (AASA, 2015).

According to Hess and Meeks (2010), school boards are more diverse than other elected officials and are typically split equally between men and women. The study used in a report from Hess and Meeks (2010) was from a stratified sample of school board members across the United States. According to the authors of the report, $80.7 \%$ of the respondents are white, $12.3 \%$ are African-American and $3.1 \%$ are Hispanic. They note that larger districts are more likely to include minority board members. Board members are educated to a much higher degree than the general adult population as well as have higher annual incomes than average. When asked to identify their general political views, $47.3 \%$ responded as moderate, $32.3 \%$ as conservatives, and $20.4 \%$ as liberals (Hess \& Meeks, 2010 p. 12-13). Hess and Meeks also reported that $56 \%$ were male and $44 \%$ were female at the time of the study. The two highest instances of occupations of board members include connections to the field of education and business. Almost a decade later, in 2018 another report was published by the National School Board Association that showed an increase in female school board members making up 50\% of this population. 78\% were White, African Americans represented $10 \%$ of the population of board members and 3\% were Hispanic or Latinx.

This summary of the comparison between the demographics of superintendents and school board members is one important aspect in providing equity in voice of both the community in schools and externally. It also provides a brief snapshot into the composition of the board and superintendent working alongside one another and how this may help or hinder their ability to communicate effectively.

\section{Relationship Between School Board and Superintendent}

Since the beginning of the shift from management of the district from the school board to the superintendent in 1837, there has been tension between these two roles. As Mowry (1894) wrote,

[f]rom the beginning, in this country, the school committees, or school boards, have had full control of the schools. When they appoint a superintendent, they do not immediately and willingly transfer the authority to him and hold him responsible for results. Far from it. They have generally made him the 'agent,' to do their bidding, and have been exceedingly careful that he does not have a chance to get the reins into his own hands and drive the team himself. (Mowry, 1894, p. 41)

Perhaps if the creation of these two distinct, yet intertwined roles had been clear and separate from the beginning, there would not be this inexorable issue pervasive today. Yet, twenty years into this century, the question of role identity remains.

Recognizing this, school boards and superintendents have an opportunity to use this challenge to strengthen their partnership to impact the systems that they represent. The discussion around areas of 
strength and conflict will include other, more specific themes that are often reflective of the politics of that time. Clear communication and opportunities to nurture relationships will also be a key theme throughout this next section.

Building and Sustaining School Board and Superintendent Relationships. Maintaining a strong relationship between the board and superintendent is vital. Nurturing this should be the responsibility of both the superintendent and the school board (Cleveland, Petersen, Sharp, \& Walter, 2000). It is important to note that while the media portrays an often troubling outlook on the relationship between the superintendent and board that results in a high superintendent turnover, there is insufficient evidence to support this notion (Grissom \& Andersen, 2012). In fact, Glass \& Franceschini (2007) found that $93 \%$ of superintendents, say their relationships with their board members are either very good or good. However, having stated this, the primary cause of superintendents exiting their position is due poor relationships and conflict between themselves and their board (Grissom \& Andersen, 2012), hence it is a fundamental component of the current dialogue.

Clearly the overarching issues that arise given any area of education are increasing demands with less resources to meet them (Merz, 1984). The only constant within the superintendent and board relationship is that there will indeed be conflict (Hoyle \& Sklyre, 1999; Mountford, 2008; Kowalski \& Brunner, 2011). On a broad level, the relationship between the superintendent and the school board can be tenuous at best. Variables that influence this relationship include the size of the district, the demographics of both the board and superintendent, political pressure the number of special interest groups within a community and the level of pressure that is exerted by such groups on the school board (Kowalski \& Brunner, 2011; Bjorke \& Lindle, 2001). Mountford (2008) also included more specific issues that these groups ought to acknowledge: a) changes of philosophy between new generations of board members, b) disparate beliefs and attitudes, c) increasing accountability, d) increasing resistance to service and e) public apathy for education (p. 85). Given the complexity of the roles, it can be difficult to nurture and sustain collaborative and trusting relationships while at the same time facing constant pressure from external forces.

Historically, the sources of tension stem from four main areas that include: a) confusion over roles and responsibilities, b) power struggles, c) motives for board service, and d) equality of representation (Mountford, 2008, p. 85). As already outlined, these issues have clearly been shown to be prevalent across the history of board governance since its inception. Glass (2000) aptly foretold the influences and pressure that multimedia would play within the politics of the district. Because of growing transparency through multimedia, this pressure results in strained relationships and power struggles that are ever more visible today. This often leads to a higher level of superintendent turnover. When the board loses faith in the authority of the superintendent to make crucial decisions for the district, that trusting relationship is weakened and/or disregarded.

School Board Evaluation Practices as a Help or Interference with Role Clarity. Analyzing the evaluation practices is an important consideration when discussing role clarity. DiPaola \& Stronge (2003) emphasized that a major problem in the evaluation process is the lack of clearly defined goals and job expectations. In fact, most of the evaluations between the board and superintendent are "neither uniform nor effective" (Mayo \& McCartney, 2004, p. 31). The results of the evaluation often reflect the one or two politically-based topics of the year or of vocal advocates representing certain issues (DiPaola \& Stronge, 2003; Mayo \& McCartney, 2004; Banks \& Maloney, 2007). Evaluation expectations add to the delicate relational balance between these roles given an ever-changing political landscape that add to the perceived success of the superintendent by the board and community. 
The superintendent (sole employee) is evaluated by five different people resulting in either averaging out the opinions or providing five different sets of feedback. Neither of these methods provide clear feedback (DiPaola \& Stronge, 2003; DiPaola, 2010). To complicate matters, school board members rarely have the expertise to perform an effective evaluation (Mayo \& McCartney, 2004; Eadie, 2008; Dawson \& Quinn, 2010; Opstad, 2010). Unfortunately, superintendents have claimed that only when relationships are strained and boards are looking for superintendent dismissal do they take the evaluation process seriously (DiPaola \& Strong, 2003).

Superintendents are often the number one source of information to the school board. This also holds true with both the data and process for evaluation (Merz, 1984; Opstad, 2010). Tekniepe (2015) found that when superintendents perceive their board members to hold the skills and knowledge to effectively evaluate the performance of the superintendent, the strength of their relational trust grows. Conversely, when the superintendent loses trust in the board often results in dismissal of the superintendent.

\section{Conclusion}

With ever-increasing accountability to meet the diverse needs of students as well as meet programmatic requirements with scarce resources, it is important to note that a growing body of research shows a connection between student learning and district level leadership-i.e. the superintendent and school board (Waters \& Marzano, 2007; Shelton, 2011). Clear and effective communication is essential to the board/superintendent relationship (Hendricks, 2013). Dervarics and O'Brien (2011) recommend that effective boards and superintendents lead as a united team, each recognizing their roles with strong collaboration and trust. The ability to manage and balance this conflict is essential to the success of the superintendent (Hoyle \& Sklra, 1999, p. 407). Therefore, it is essential that the superintendent create and sustain open dialogue, provide opportunities for board input on strategies, procedures and facilitate a team approach to decision making (Banickis \& Pancha, 2011).

It is also critical that the superintendent provide input into the evaluation process to ensure alignment of evaluation with actual responsibilities (Hendricks, 2013). This helps to maintain a clear channel of communication regarding a shared vision between and amongst the group members. Proactively developing and implementing a clearly defined evaluation process is essential to foster relationships between the board and the superintendent. It is also a means for providing direction and protecting the superintendent during times of stress or turmoil due to political pressure, district issues or relational conflict. This process is critical for clarifying the role of the superintendent and promoting dialogue around the role of the board to help nurture this relationship. Ongoing team building, education and professional development are key components of not only clarifying respective roles but also deepening and nurturing relationships that are key to successful educational leadership.

\section{References}

American Association of School Administrators. (2015). Study of the American superintendent: 2015 mid-decade update. URL: https://www.aasa.org/policy-blogs.aspx?id=39344\&blogid=84002

Alsbury, T. L. (2015). Improving School Board Effectiveness: A call for balanced governance. In T. Alsbury \& P. Gore (Eds.), Improving school board effectiveness: A balanced governance approach, pp. 313. Cambridge, MA: Harvard Education Press

Banks, P. A., \& Maloney, R. J. (2007, June). Changing the subject of your evaluation. In School Administrator. URL: http://www.policygov.com/documents/ChangingSubjectJune2007.pdf 
Banickis, B. \& Pacha, J. (2011). Illinois board of education closed sessions: Does the superintendent make a difference? In Connexious Content Commons. URL: http://cnx.org/content/m41413/1.1/

Bartanen, B., Grissom, J. A., Joshi, E. \& Meredith, M. (2018). Mapping Inequalities in Local Political Representation: Evidence from Ohio school boards. In AERA Open, Vol. 4(4), pp 1-19. URL: https://journals.sagepub.com/doi/full/10.1177/2332858418818074

Bjork, L., Glass, T., \& Brunner, C. (2005). Characteristics of American school superintendents. In L. Bjork \& T. Kowalski (Eds.), The Contemporary Superintendent: Preparation, Practice and Development. Thousand Oaks, CA: Corwin Press, pp. 19-43.

Björk, L., Kowalski, T., \& Browne-Ferrigno, T. (2014). The school district superintendent in the United States of America. In Educational Leadership Faculty Publications. URL: http://ecommons.udayton.edu/eda fac pub/13

Björk, L. G., \& Lindle, J. C. (2001). Superintendents and Interest Groups. In Educational Policy Vol. 15(1), pp. 76-9.

Bogotch, I. (2004). A history of public school leadership: The first century, 1837-1942. DOI: 10.4135/9781412980036.n2.

Callahan, R. E. (1966) The superintendent of school: A historical analysis. In Final report of project S212. Washington, DC: U.S. Office of Education, Department of Health, Education, and Welfare. URL: https://files.eric.ed.gov/fulltext/ED010410.pdf

Cistone, P. J. (2008). School board research: A retrospective. In T. Alsbury \& P. Gore (Eds.), Improving school board effectiveness: A balanced governance approach. Cambridge, MA: Harvard Education Press, pp. 25-33.

Cleveland, P., Petersen, G., Sharp, W., \& Walter, J. (2000). A three state examination of school board evaluations of superintendents. In Educational Research Quarterly, 23(3).

Dawson, L. J., \& Quinn, R. (2010). Superintendent Evaluation: A Travesty that Need Not Be. American Association of School Administrators. In New Superintendents E-Journal. URL: http://www.aasa.org/content.aspx?id=16358

Dervarics, C., \& O’Brien, E. (2011). Eight characteristics of effective school boards: Full report. Center for Public Education. URL: https://www.nyssba.org/clientuploads/nyssba pdf/Events/nsbmabuffalo-07152016/Eight-characteristics-of-effective-school-boards -full-report.pdf

DiPaola, M.F. \& Stronge J.H. (2003) Superintendent Evaluation Handbook. Lanham, MD: Scarecrow Press, Inc.

DiPaola, M. (2010). AASA whitepaper: Evaluating the superintendent. American Association of School Administrators. URL:

https://www.aasa.org/uploadedFiles/Resources/AASA White Paper on Superintendent Evaluatio n.pdf

Draper, A., Powell, W., \& Poland, A. (1895). Report of the Committee of Fifteen on Elementary Education with the Reports on the Sub-committees: on the trainings of teachers; on the correlation of studies in elementary education; on the organization of city school systems. In Educational Review, IX, pp. 304-322.

Eadie, E. (2008). The board-superintendent Rx. In American School Board Journal, 195 (7), pp. 44-45.

Ellis, A., Golz, R., \& Mayrhofer, W. (2014). The education systems of Germany and other European countries of the $19^{\text {th }}$ century in the view of American and Russian Classics: Horace Mann and Konstantin Ushinsky. In International Dialogues on Education: Past and Present, Vol. 1, Nr. 1. URL: http://www.ide-journal.org/wp-content/uploads/2014/01/IDE-2014-1-full.pdf, pp. 7-28. 
Fusarelli, B., \& Fusarelli, L. (2005). Reconceptualizing the superintendency: Superintendents as applied social scientists and social activists. In L. Bjork \& T. Kowalski (Eds.). In The Contemporary Superintendent: Preparation, Practice and Development. Thousand Oaks, CA: Corwin Press, pp 187-206.

Gersman, E. M. (1970). Progressive reform of the St. Louis school board, 1897. In History of Education Quarterly Vol. 10(1), pp. 3-21. URL: http://www.jstor.org/stable/367047

Gemberling, K. W., Smith, C. W., \& Villani, J. S. (2000). The key work of school boards guidebook. Alexandria, VA: National School Boards Association. URL: http://www.schoolinfosystem.org/archives/NSBA-KeyworkGuidebook.pdf

Glass, T. E., Björk, L. G., \& Brunner, C. C. (2000). The Study of the American school superintendency, 2000. Arlington, VA: American Association of School Administrators.

Glass, T. E, \& Franceschini. L. A. (2007) The state of the American school superintendency: A mid-decade study. Arlington, VA: American Association of School Administrators. Lanham, MD: Rowman \& Littlefield Education.

Grissom, J. A., \& Andersen, S. (2012). Why superintendents turn over. In American Educational Research Journal. Vol. 49, No. 6. pp. $1146-1180$.

Hendricks, S. (2013). Evaluating the superintendent: The role of the school board. In NCPEA Education Leadership Review, Vol. 14, No. 3, pp. 62-72.

Hess, F. M., \& Meeks, O. (2010). School boards circa 2010: Governance in the accountability era. N.p.: The National School Boards Association, The Thomas B. Fordham Institute, and The Iowa School Boards Foundation. URL: $\underline{\text { https://files.eric.ed.gov/fulltext/ED515849.pdf }}$

Hoyle, J. R., \& Skrla, L. (1999). The politics of superintendent evaluation. In Journal of Personnel Evaluation in Education, 13 (4), pp. 405-419.

Kirst, M. W. (2008). The evolving role of school boards: Retrospect and prospect. In T. L. Alsbury (Ed.). The future of School Board Governance. Lanham, MD: Rowman \& Littlefield Publishers, pp. 37-60.

Kowalski, T. J. (1999). Leadership in the larger community. In The School Superintendent: Theory, practice, and cases, pp. 313-341. URL: http://ecommons.udayton.edu/eda fac pub/50

Kowalski, T.J. (2005). Evolution of the school superintendent as communicator. In Communication Education, Vol. 54, No. 2, pp. 101-117.

Kowalski, T. (2005) Evolution of the school district superintendent position. In Kowalski, T., \& Bjork, L. (Eds.). In The contemporary superintendent: Preparation, practice and development. Thousand Oaks, CA: Corwin Press, pp. 1-18.

Kowalski, T. J., \& Brunner, C. C. (2011). The school superintendent: roles, challenges, and issues. In Sage handbook of educational leadership: Advances in theory, research, and practice, pp. 142-16. URL: http://ecommons.udayton.edu/eda fac pub/43

Mayo, C. R. \& McCartney, G. P. (2004). School superintendents' evaluations: Effective and results-based? In ERS Spectrum, Vol. 22(1), pp. 19-33.

Kowalski, T., \& Keedy, J. (2005). Preparing superintendents to be effective communicators. In Kowalski, T. \& Bjork L. (Eds.). The contemporary superintendent: Preparation, practice and development. Thousand Oaks, CA: Corwin Press, pp. 1-18.

Merz, C. S. (1984). Conflict and frustration for school board members. New Orleans, LA: American Educational Research Association. URL: https://files.eric.ed.gov/fulltext/ED244358.pdf

Mowry, W. A. (1895). Powers and duties of school superintendents [Google Play Books version]. URL: https://play.google.com/books/reader?id=FrvXMwVrmQcC\&hl=en\&pg=GBS.PA38:

Mountford, M. (2008). Historical and current tensions among board-superintendent teams: Symptoms or cause? In T. Alsbury (Ed.) The future of School Board Governance. Lanham, MD: Rowman \& Littlefield Publishers, pp. 37-60. 
National School Board Association \& K12 Insight (2018). K12 national survey: Today's school boards \& their priorities for tomorrow. URL:

https://cdn-files.nsba.org/s3fs-public/reports/K12_National Survey.pdf?5XEOPBQlubbzr9x.8_5rFr BRugkHKS7N

Nir, A., \& Eyal, O. (2003). School-based management and the role conflict of the school superintendent. Journal of Educational Administration, 41.

Newsom, N. W. (1932). The legal status of the county superintendent (Report No. 7). Washington. D.C.: Superintendent of Documents, Government Printing Office. URL: file://C:/Users/zhouy2/Downloads/ttu be0001_000607.pdf

Opstad, T. A. (2010). Superintendent evaluation: A review of small-school models (Doctoral dissertation). URL: http://www.dissertations.wsu.edu/Dissertations/Spring2010/t opstad 031710.pdf

Shelton, T. (2015). Transforming beliefs into action: board and superintendent teams working together. In T. Alsbury \& P. Gore (Eds.). Improving school board effectiveness: A balanced governance approach. Cambridge, MA: Harvard Education Press, pp. 33-42.

Stephens, L. (2007) WWW Superintendents. In Journal of Philosophy \& History of Education, 57.

Stufflebeam, D. L. (1994). Evaluation of superintendent performance: Toward a general model. Kalamazoo, MI: Center for Research in Educational Accountability and Teacher Evaluation (CREAT).

Tekniepe. R. J. (2015). Identifying the factors that contribute to involuntary departures of school superintendents in rural America. In Journal of Research in Rural Education, 30(1), pp. 1-13.

Waters, J. T., \& Marzano, R. J. (2007). School district leadership that works: The effect of superintendent leadership on student achievement. In ERS Spectrum, Vol. 25(2), pp. 1-12.

\section{About the Author}

Dr. Robin L. Henrikson: PhD, Assistant Professor of Education, Director of Assessment, School of Education, Seattle Pacific University; e-mail: henrir@spu.edu 